\title{
Print It To Me Development System
}

\author{
Haezel Ann Dickenn a , Azizul Azhar Ramli a , Zuraini Ali Shah ${ }^{\mathrm{b}}$, Shahreen Kasim a, \\ ${ }^{a}$ Faculty Computer Science and Information Technology, Universiti Tun Hussein Onn Malaysia, 86400, Parit Raja, Batu Pahat, Johor, Malaysia \\ ${ }^{\mathrm{b}}$ School of Computing, Faculty of Engineering, Universiti Teknology Malaysia \\ -haeze196dicken@gmail.com, \\ * corresponding author
}

\section{ARTICLE INFO}

\section{Article history}

Received

Revised

Accepted

Keywords

Palm Oil, Diagnostic

\section{ABSTRACT}

This paper addresses the project where, by the end of the project, the web-based system is able to provide an online printing service system to any party or individual who are staying in-campus to make money with their personal printer. In-campus student and staff are allowed to register as service provider (SP) and they can view and accept order via this webbased system. The system are able to display and show requests by customers while the service providers can select the requests and provide proper service to them. Furthermore, the system should have limitless availability of access, compared to the current printing request process.

\section{Introduction}

It has been years since the Universiti Tun Hussein Onn Malaysia (UTHM) was built, and since then the university has been approving and providing places in-campus for staff and students to operate their ownlimited printing services. These printing services differ from each other in the aspects of location, payment, quality and services. Most printing services in UTHM are self-service printing which mostly are managed by students, and printing services run by staff are more kept under surveillance.

The existing process of printing service is students need to find the best printing stall or shop in the campus that suits their preferences which are nearby. Most students prefer self-service printers compared to printing shops, where no one would monitor them while printing. For online printing services, students need to visit the printing services' website, only if they provide one.

Most of the time students encounter difficulties with the existing process of printing services such as they had to make choices of the best printing shops that meet their preferences. In order for them to do that, they need to survey all the printing stalls which requires travelling and effort. Another difficulty is that most printing stalls open during working hours only, which makes printing services not available at all times, some are closed during holidays. Since most of the printers are self-service, some students tend to be destructive and irresponsible during printing.

Therefore this project is aimed to overcome those difficulties. This project entitled "Print It To Me" is a web-based system that give opportunities to any person or organization who owns a printer to provide printing services online.

\section{Related Works}


Vol. 1, No.1, July 2019, pp. 24-42

This section discusses the domain background of the project, related terms, technology used, and the study of related system to the project, as well as the comparison of similar systems.

\section{A. Domain Background}

In 2010, the Liaison Committee for Academic Computing and Technology (LCACT) carried out and produced an analysis research on Student Printing [1]. One of the main topics that this analysis addresses is the problem of equity of access to printing. Oxford dictionary [2] defines equity as the quality of being fair and impartial. According to the analysis, a couple of student divisions in the campus are fairly easily accessed to printing services due to the students getting use of printers in departmental labs and classrooms. On the other hand, another couple of student division do not have the accessibility to labs or classrooms that provides printing services. Approximately $60 \%$ of the students of Union College are restrained from having easy-accessed printing services, which imbalances the equity issue. One of the key proposals of this analysis is there should be provided at least one printing service on-campus site that is available at all times.

\section{B. Technology Used}

SQL Server Data Tools is going to be used as the database platform. The developing tool needed is Microsoft Visual Studio 2015, an integrated development environment (IDE) from Microsoft. It is used to develop computer programs for Microsoft Windows, as well as web sites, web apps, web services and mobile apps. Visual Studio uses Microsoft software development platforms such as Windows API, Windows Forms, Windows Presentation Foundation, Windows Store and Microsoft Silverlight. It can produce both native code and managed code [3].

\section{Study of Similar System}

\section{1) Printt (URL: https://printtapp.com/)}

Printt is a printer system that provides free printing services for university students in exchange for watching advertisements [4]. When logged in, user simply upload documents to the cloud and locate the nearest Printt printer in the student union or accommodation. As long the user is within 5 metres of a machine they can print to any A4 specification. Printt's map will show user where the closest printer is. One of the downside to this application is that Printt user can only access the printer in a Printt app-enabled area, where Bluetooth is used to connect the smartphone and printer. Which specifies only to certain areas or communities that implements these technologies can have access to the free printing app, and any other disallowed printer cannot be used.

\section{2) Princh (URL: https://princh.com/)}

Princh is a Danish software company founded in 2014 developing cloud printing solutions [5]. At this point, the document will be uploaded to the Princh cloud. The user then selects the desired nearby printer entering the printer ID number or scanning the QR-code located on top of the printer, pays with their credit card or other preferred payment option and the print job is carried out. Printer owners get access to a personal control panel where they can set print prices and monitor all Princh activity for their business. Installing Princh is free for printer owners. Princh gets a small fee per 
Vol. 1, No.1, July 2019, pp. 24-42

print job. The weakness of this system is that has not yet reached worldwide, which means that it is only available in Denmark. People from all over the world who are interested in the system and would like to try to get service from the system can sign up as a Princh user, but may not yet have access to the selected printers.

3) VistaPrint (URL: https://www.vistaprint.com/) Vistaprint, a Cimpress company, offer customized

marketing materials and printed products for business or personal use to fit any budget, style and occasion. Whatever the size or stage of the business and whatever the design skills, they give the tools and support needed to bring vision to life. The downside of VistaPrint is that it is a standard web service system that provides printing system to customers. The website is specifically developed for its company, and does not give job-opportunities to other users to work externally from their company. The company is mainly in North America and Europe, which delivery will be charged very high to other places.

\section{4) Proposed System}

The proposed system, entitled Print It To Me, is a Web-based system that aims to solve the problem of printing experience among UTHM students. This system has two main functions which are users are able to do part-time jobs when registered as Service Providers (SP), and detection of all printing requests in UTHM.

There are two categories of users in the system, which are users as customers and users as SP. Customer are the one who are requesting printing of their documents at any flexible time. Customers only need to upload their documents and fill in the printing preferences. Customer details are required during registration. The customers will be notified when the documents are already printed and being delivered to them. Customers can give feedback to the website.

For service providers (SP), after logged in, the SP should see a list of all customer requests that are not yet fulfilled. SP can choose which customer they would like to give service to, based on their details. After finish printing, the SP should contact the customer and negotiate further about deliveries.

Table 1. Comparison of Printing Systems

\begin{tabular}{|c|c|c|c|c|}
\hline $\begin{array}{c}\text { Features/ } \\
\text { System }\end{array}$ & Printt & Princh & VistaPrint & Print It To \\
& & & & Me \\
\hline System & Application & Cloud- & Web-based & Web-based \\
& and Web- & based & & \\
& based & & & \\
\hline
\end{tabular}


Vol. 1, No.1, July 2019, pp. 24-42

\begin{tabular}{|c|c|c|c|c|}
\hline $\begin{array}{c}\text { User } \\
\text { Registration }\end{array}$ & Needed & Needed & Needed & Needed \\
\hline $\begin{array}{c}\text { Payment } \\
\text { Requirement } \\
\mathrm{s}\end{array}$ & Unrequired & Printing & $\begin{array}{l}\text { Documents } \\
\text { and delivery }\end{array}$ & $\begin{array}{c}\text { Documents, } \\
\text { delivery, SP } \\
\text { one-time } \\
\text { registration }\end{array}$ \\
\hline $\begin{array}{l}\text { Application } \\
\text { Installation }\end{array}$ & Required & Required & Unrequired & Unrequired \\
\hline $\begin{array}{c}\text { Job } \\
\text { Opportunitie } \\
\text { s to Users }\end{array}$ & Unavailable & Available & Unavailable & Available \\
\hline Target Users & Students & $\begin{array}{c}\text { Service } \\
\text { Providers }\end{array}$ & Customers & $\begin{array}{c}\text { Service } \\
\text { Providers } \\
\text { and students }\end{array}$ \\
\hline Delivery & $\begin{array}{c}\text { Not } \\
\text { required }\end{array}$ & $\begin{array}{c}\text { Not } \\
\text { required }\end{array}$ & Required & $\begin{array}{c}\text { SP can } \\
\text { deliver, but } \\
\text { customer can } \\
\text { also pick-up } \\
\text { document }\end{array}$ \\
\hline
\end{tabular}

Table 1 shows the comparison between the proposed printing system and printing system from Printt, Princh and VistaPrint. The comparison between these three systems allow deeper understanding of the system

requirements, functionalities, advantages and disadvantages. The criteria for comparison are the important features that defines a printing system. 


\section{Methadology}

This section explains the methodology used during the completion of this project. For this project, Waterfall model was selected as the most suitable methodology for the system development life cycle (SDLC) to complete the system. The SDLC is split into four phases which are the planning and analysis phase, design phase, implementation phase and testing phase [6]. Waterfall model is the selected most suitable methodology for this project because the requirements of the projects are well-known since the project should produce a web-based system by the end. This helps in reducing the time to accomplish the project using Waterfall methodology. This methodology needs to keep detailed records of the project. Having such records will allow the existing system to be improvised in the future. With the Waterfall methodology, clients can have an overview idea of how the system should be by the end of the project. They will have an idea of the size, cost and timeline of the project. In case of a turnover happens, the methodology's strong documentation and record keeping help to reduce the minimal project impact.

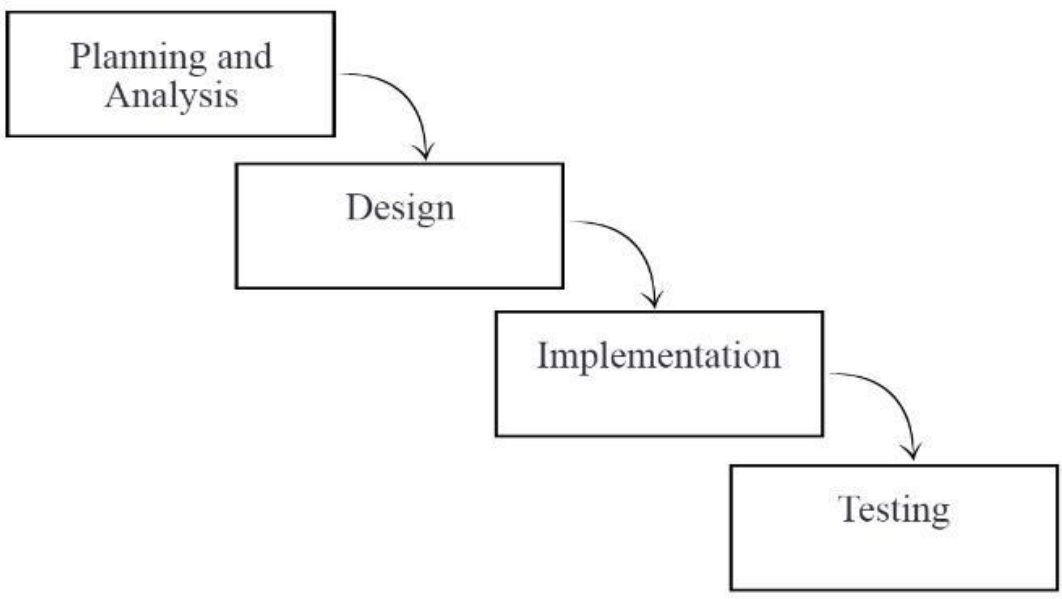

Figure 1. Waterfall process

Table 2. Workflow for the development of proposed Application

\begin{tabular}{|l|l|l|}
\hline Phases & \multicolumn{1}{|c|}{ Activities } & \multicolumn{1}{c|}{ Output } \\
\hline \multirow{3}{*}{$\begin{array}{l}\text { lentification of project } \\
\text { bjectives, problem statement, }\end{array}$} & $\begin{array}{l}\text { 1. 'roposal } \\
\text { 2. iterature review }\end{array}$
\end{tabular}


Vol. 1, No.1, July 2019, pp. 24-42

\begin{tabular}{|c|c|c|}
\hline Planning & $\begin{array}{l}\text { roject scope, project } \\
\text { gnificance and expected results } \\
\text { f project. } \\
2 \text {.esearch on the proposed system } \\
\text { ased on online resources, related } \\
\text { surnal and existing similar } \\
\text { ystems. } \\
\text { tudy on the strengths and } \\
\text { reaknesses of the existing } \\
\text { milar systems. } \\
4 \text { lotting the project schedule. }\end{array}$ & $\begin{array}{l}\text { 3. 'omparison } \\
\text { nalysis table } \\
\text { etween existing } \\
\text { pplications. } \\
\text { 4. } \text { jantt chart }\end{array}$ \\
\hline Analysis & $\begin{array}{l}1 \text { lentification and evaluation on } \\
\text { se features of proposed system } \\
\text { ased on comparison with the } \\
\text { milar existing systems made } \\
\text { uring planning phase. } \\
2 \text { lentification of the users of the } \\
\text { roposed system }\end{array}$ & $\begin{array}{l}\text { 1. Jser requirement } \\
\text { 2. 'unctional } \\
\text { equirement } \\
\text { 3. Jon-functional } \\
\text { equirement } \\
\text { 4. ystem flow chart }\end{array}$ \\
\hline
\end{tabular}

\begin{tabular}{|c|c|c|c|}
\hline & & $\begin{array}{l}\text { Determination of the hardware } \\
\text { nd software requirements to } \\
\text { evelop the proposed system. }\end{array}$ & \\
\hline Design & 1. & $\begin{array}{l}\text { nprovise the system flowchart } \\
\text { nd entity relationship diagram } \\
\text { 玉RD). }\end{array}$ & $\begin{array}{l}\text { 1. )ynamic interface } \\
\text { esign } \\
\text { 2. ) atabase design }\end{array}$ \\
\hline & & lesign the system architecture & \\
\hline
\end{tabular}


Vol. 1, No.1, July 2019, pp. 24-42

\begin{tabular}{|c|c|c|}
\hline & hich are interface and database. & \\
\hline $\begin{array}{c}\text { mplementati } \\
\text { on }\end{array}$ & 1. xecution of the proposed system & $\begin{array}{l}\text { 1. )ynamic interface } \\
\text { esign } \\
\text { 2. )atabase design }\end{array}$ \\
\hline Testing & 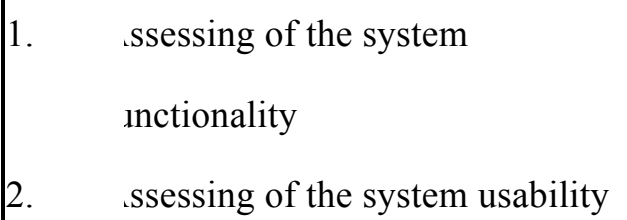 & $\begin{array}{l}\text { 1. 'est cases } \\
\text { 2. 'eedback of the } \\
\text { ystem }\end{array}$ \\
\hline
\end{tabular}

In the planning and analysis phase, information gathering was conducted through searching, accessing and researching journals, books or any articles relevant to the project. Studies on similar system of printing services was also made during this phase. The functions of each system were carefully observed to know more detailed about what is needed for the proposed system. Analysis based on the project requirements, functional, technical and usability, are also being carried out to identify the feasibility of the system. For the project timeline, Gantt-chart is used in the project to properly estimate and allocate each phases during the project development. Proper time management reduces the time taken to finish the project and helps the project to be done on time.

In the design phase, the general characteristics of the system are defined. The data storage and access for the database layer are designed. The user interface at the desktop layer is designed using wireframe sketches to make a view of how the system is going to look like in the end. The design of the system must be user-friendly and dynamic to ensure that user will always be attracted to the web system and will visit the site again. In this phase, the coding of the system is implemented based on the inputs achieved from the system design. The interface of the webbased system is built using Visual Studio platform, in HTML, PHP and C\#. The interface should be dynamic and user-friendly just as proposed in the design phase. The database is also developed using SQL Server Data Tools. There should be two database tables, for customers and SP.

In the testing phase, the system should be tested based on usability testing and functional testing. Usability testing allows users, both customers and SP, to test the system whether or not the requirements for the usability of the system is accomplished as intended in the dataflow diagram and database scheme. Functional testing focuses on the features of the system where test plans are required to test the expected result outcome of the system.

\section{A. Hardware Requirement}


Vol. 1, No.1, July 2019, pp. 24-42

The minimum specification of hardware requirement that is needed to build the Print It To Me system is stated in Table 3.

Table 3. Hardware requirement for Print It To Me development

\begin{tabular}{|l|c|c|}
\hline No. & Hardware & Specification \\
\hline 1. & Personel Computer & HP Pavillion \\
\hline 2. & Central Processing Unit & Intel Core i5-5200U @ \\
& $(\mathrm{CPU})$ & $2.20 \mathrm{GHz}$ processor \\
\hline 3. & Random Access Memory & $4 \mathrm{~GB}$ \\
& (RAM) & Windows 10 \\
\hline 4. & Operating System & \\
\hline
\end{tabular}

\section{B. Software Requirements}

The specification of software requirement that is needed to build the Print It To Me system is Microsoft Visual Studio 2015 with an integrated SQL Server Data Tools.

\section{System Analysis and Design}

This section discusses the analysis and design of the system. In the analysis phase, data collection would be carried out in order to identify the specifications for the proposed system.

\section{A. System Requirement Analysis 1) Functional Requirements}

A functional requirement defines a function of a system or its component [7]. These requirements are identified during the analysis of user requirement. Table 5 shows the functional requirements for the proposed system.

Table 5. Functional requirements of the proposed system

\begin{tabular}{|c|c|}
\hline No. & Functional Requirements \\
\hline 1. & $\begin{array}{l}\text { The system should allow user to login using valid username } \\
\text { and password. }\end{array}$ \\
\hline 2. & $\begin{array}{l}\text { The system should prohibit entry of user with invalid username } \\
\qquad \text { or password. }\end{array}$ \\
\hline 3. & $\begin{array}{c}\text { The system should allow user to view the list of customer } \\
\text { requests. }\end{array}$ \\
\hline 4. & $\begin{array}{c}\text { The system should allow user to view the information of } \\
\text { requests. }\end{array}$ \\
\hline
\end{tabular}


Vol. 1, No.1, July 2019, pp. 24-42

\begin{tabular}{|c|c|}
\hline 5. & $\begin{array}{c}\text { The system should alert the user when the request has been } \\
\text { done by the service provider. }\end{array}$ \\
\hline 6. & The system should allow user to view the status of printing \\
& request. \\
\hline
\end{tabular}

2) Non-functional Requirements

Non-functional requirements defines the operations of

a. system [7]. There are several types of non-functional requirements. Table 6 show the nonfunctional requirements for the proposed system.

Table 6. Non-functional requirements of the proposed system

\begin{tabular}{|c|c|}
\hline Requirements & Explanation \\
\hline Operational & $\begin{array}{r}\text { The system should alert the user when the request } \\
\text { has been done by the service provider. }\end{array}$ \\
\hline Performance & No special performance requirements are \\
anticipated.
\end{tabular}

\section{B. System Design}

1) Data Flow Diagram

A data flow diagram (DFD) is a graphical figure of the flow of data in a system. Information or data of the system that flows into the system as input and out from the system as output, and how the data be stored on the system are shown in the DFD [19].

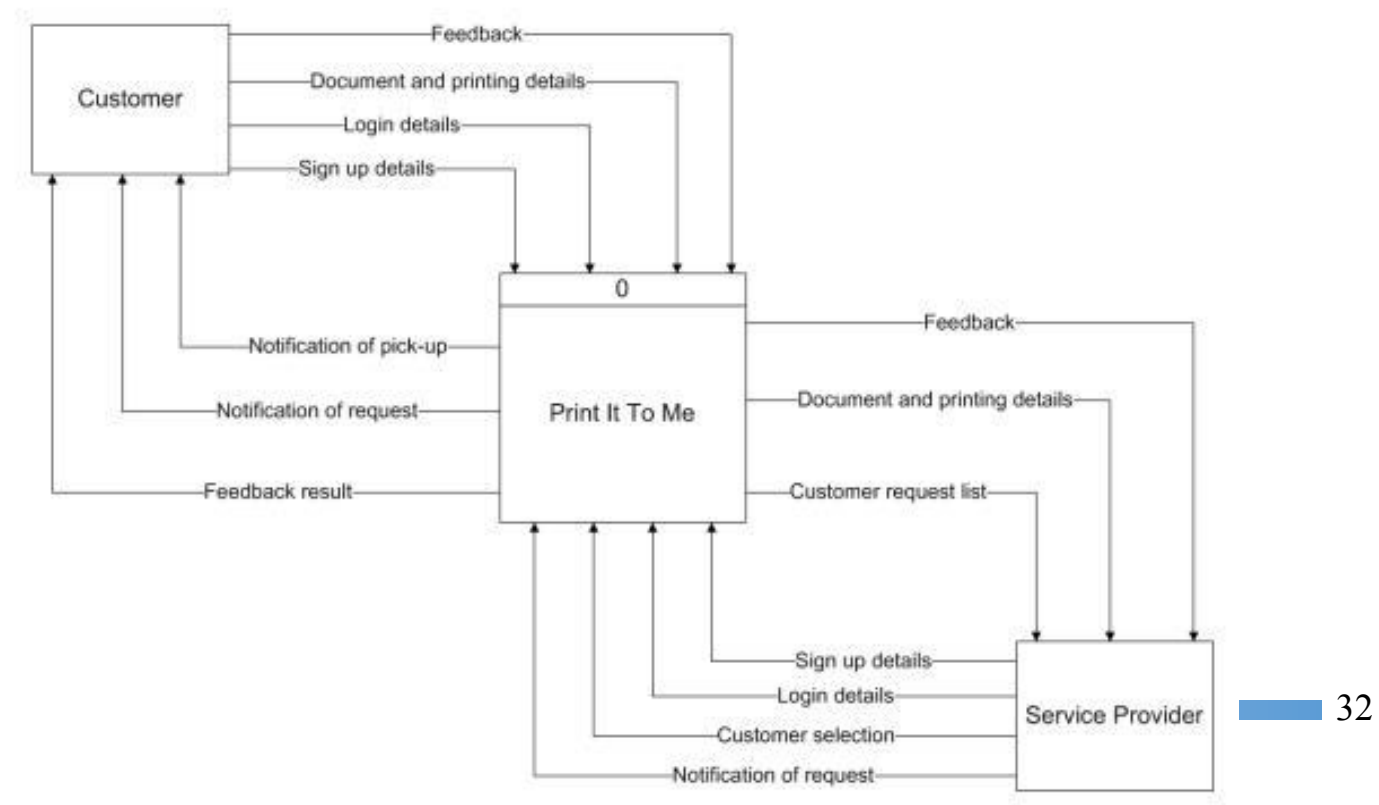


Figure 2. Context Diagram of Print It To Me

Figure 2 illustrates the context diagram of the system in general. Customer and Service Provider (SP) are two of the entities that involve in the system. Customers and SP can provide sign up and login details to enter the system. Customers are able to upload document and printing details if they wish to make printing requests, and give feedback of the SP that picked them out. $\mathrm{SP}$ are able to select the customers they want to give printing service to, and send notification to the customer once they have finished their request.

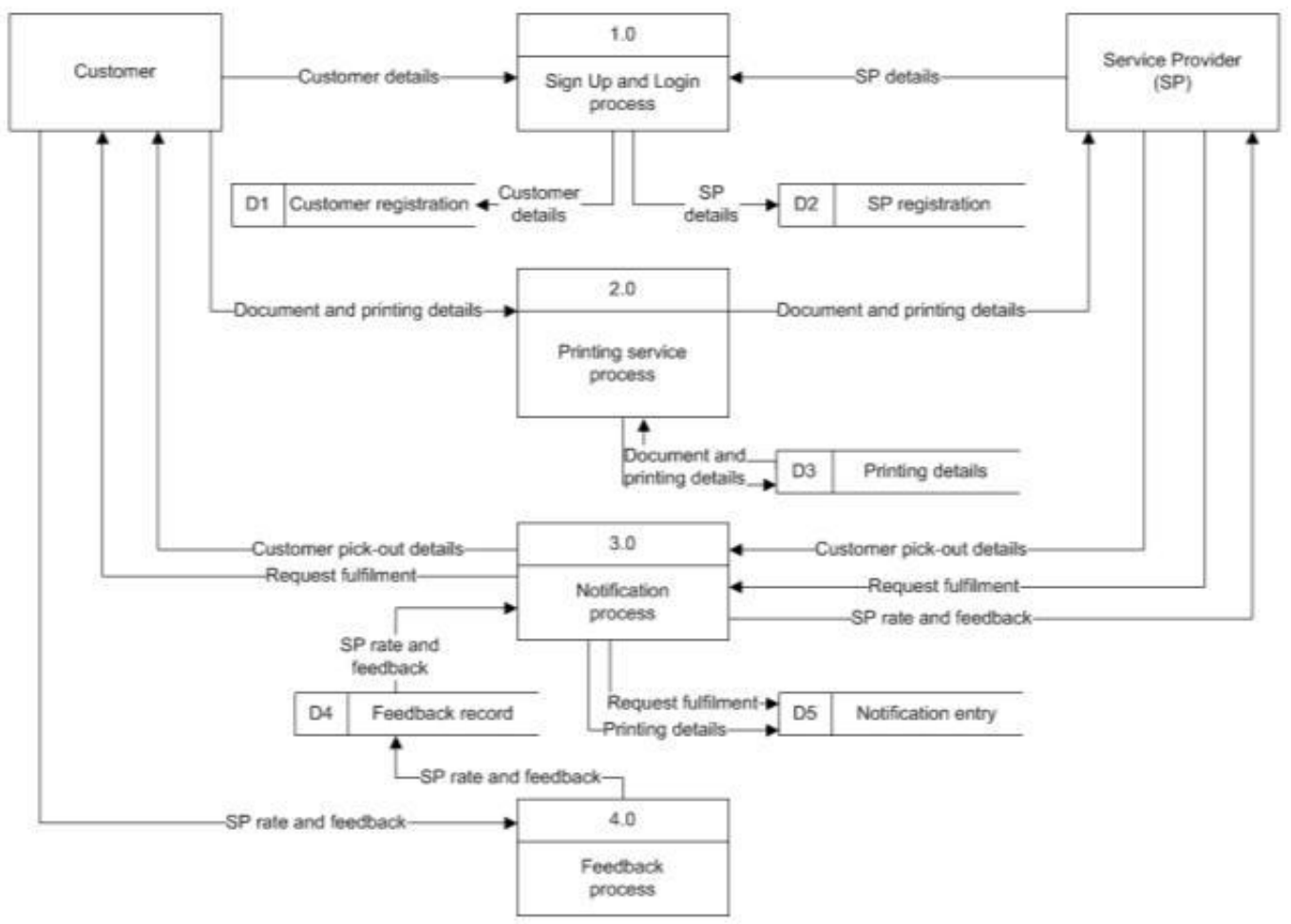

Figure 3: DFD Level 0 of Print It To Me

Figure 3 illustrates the DFD Level 0 of the system where there are four main processes involved. Process 1.0 is the sign up and login process where both users must fill in their details in order to use the system. Their details will be kept in different data stores, D1 is the data store for customers, and D2 is the data store for SP. Process 2.0 is the printing service process where it requires 
Vol. 1, No.1, July 2019, pp. 24-42

Customer to input document and printing details, which will be stored in D3, and if a SP chooses to give printing service to the customer, the process outputs the documents and printing details to the SP. The third process, 3.0 is the notification process, where SP will notify when he picks out a customer request and after he is done giving printing services. These will be updated into data store D5. The fifth process, 4.0 is the feedback process where customer can rate and give feedback to the user. The feedback will be stored in data store D4 and will notify the SP about the feedback.

\section{2) Flow Chart}

A flowchart is a diagram of the movement sequence or actions the users perform based on the flow of the system. A flowchart helps visualize what is going on and thereby help understand a process, and perhaps also find flaws, bottlenecks, and other less-obvious features within it [9].

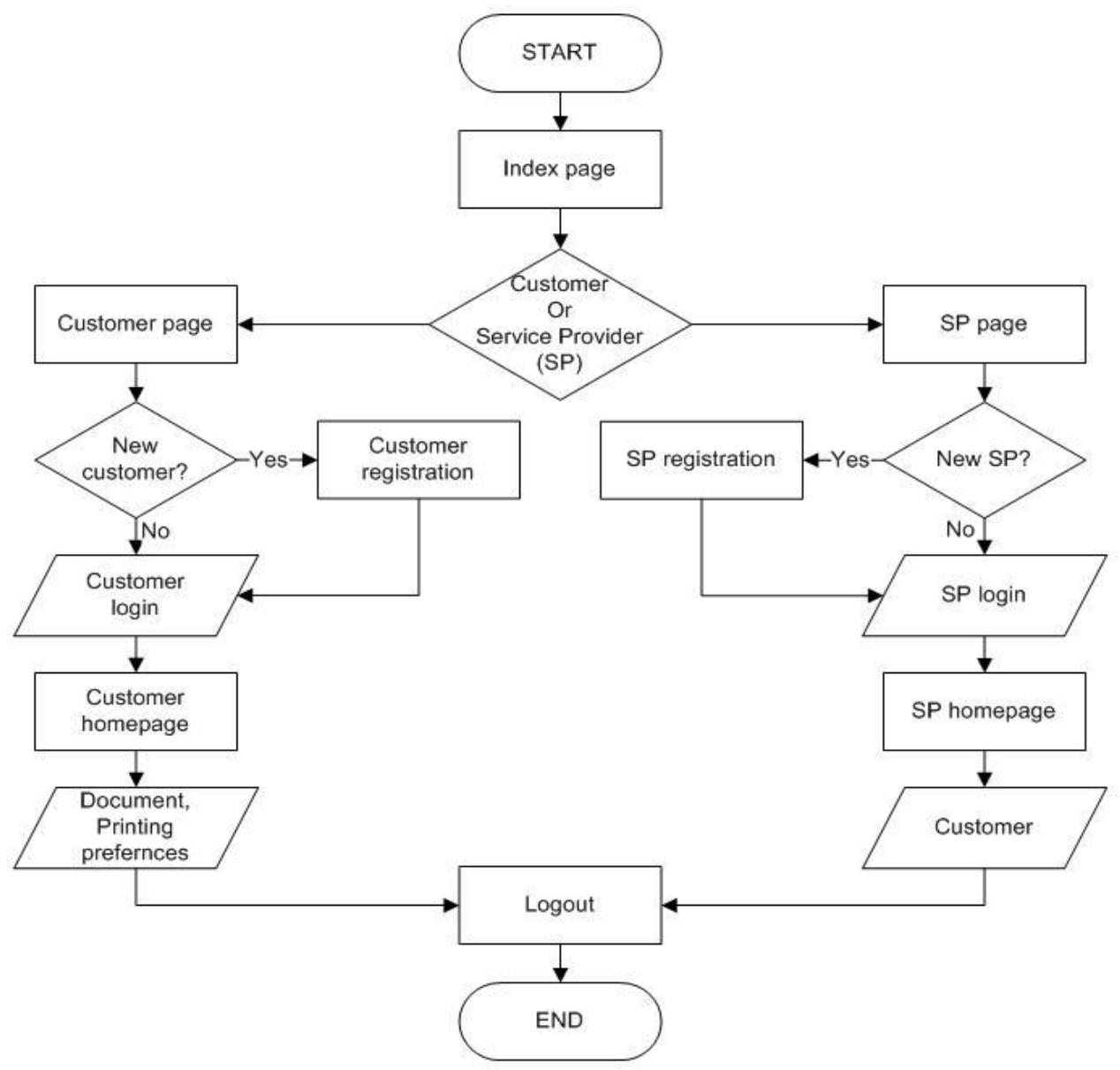

Figure 4. Flowchart of Print It To Me System in general 
Figure 4 shows that both users, Customer and SP, need to enter an index page when the web system appear, where there will be two choices to make. The user either enters the system as a Customer or a SP. If the user is new to the system, they may choose to register either one of the users, or both. After registering as the system user, they are redirected to a homepage of the respective user they have chosen, either Customer or SP. From there, they choose what action they would like to make based on their purpose of using the system, where as a Customer, they can request printing services, and as a SP, they can choose customers to provide printing service.

\section{3) Entity Relationship Diagram}

Entity Relationship Diagram (ERD) is a data modeling technique that graphically illustrates an information system's entities and the relationships between those entities. An ERD is a conceptual and representational model of data used to represent the entity framework infrastructure [10]. Figure 5 illustrates the ERD of the proposed system.

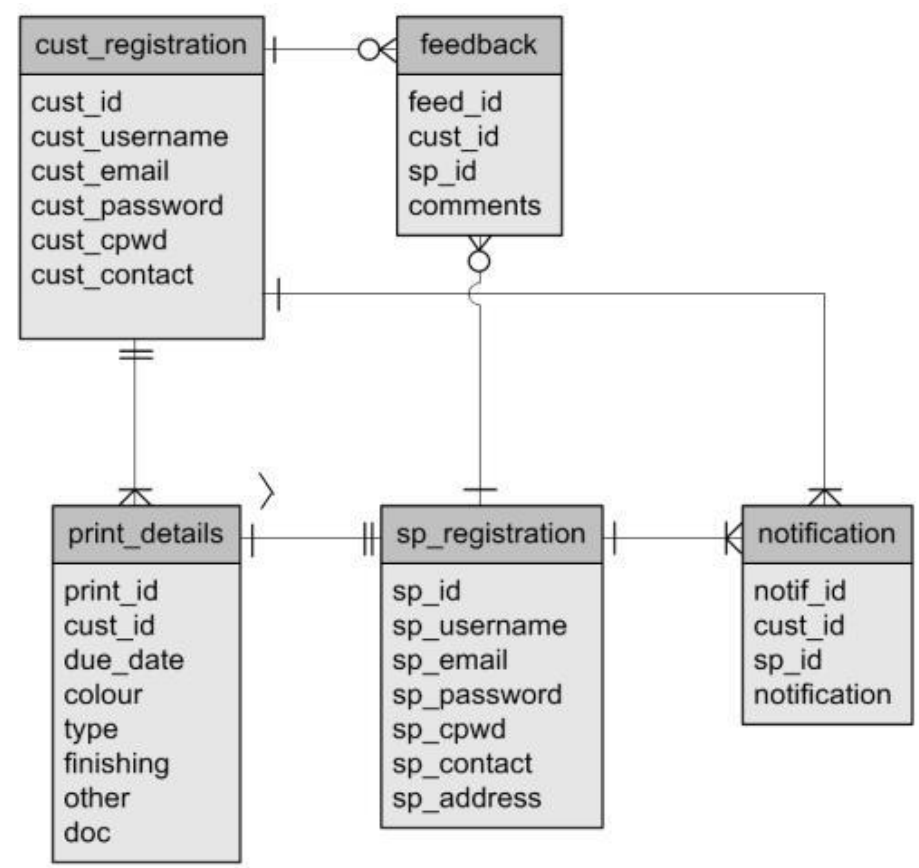

Figure 5. ERD of the proposed system 
Vol. 1, No.1, July 2019, pp. 24-42

Figure 5 shows the ERD of Print It To Me where there are five entities, each representing tables in the database of the system. The entities are cust_registration, print_details, sp_registration, notification and feedback, which represent customer, printing request, service provider (SP), notification and feedback respectively. Customer can make one or more printing request, while printing request can have one and only one customer. Printing request can be selected by one and only one SP, while SP can take one or many printing request. SP can make one or more notification, while a notification is made by one SP. A notification is sent to a customer, while a customer can have one or more customer. A customer can submit zero to many feedback, while a feedback is made by a customer. A feedback is sent to an SP, while an SP can have zero to many feedback.

\section{User Interface Design}

User interface is by means the user and the system

can interact, where it is very important to develop it because a user interface should be userfriendly and attractive to the customer [11]. Figure 6 displays the index page of the Print It To Me system, where user can sign in as a customer or a SP. 


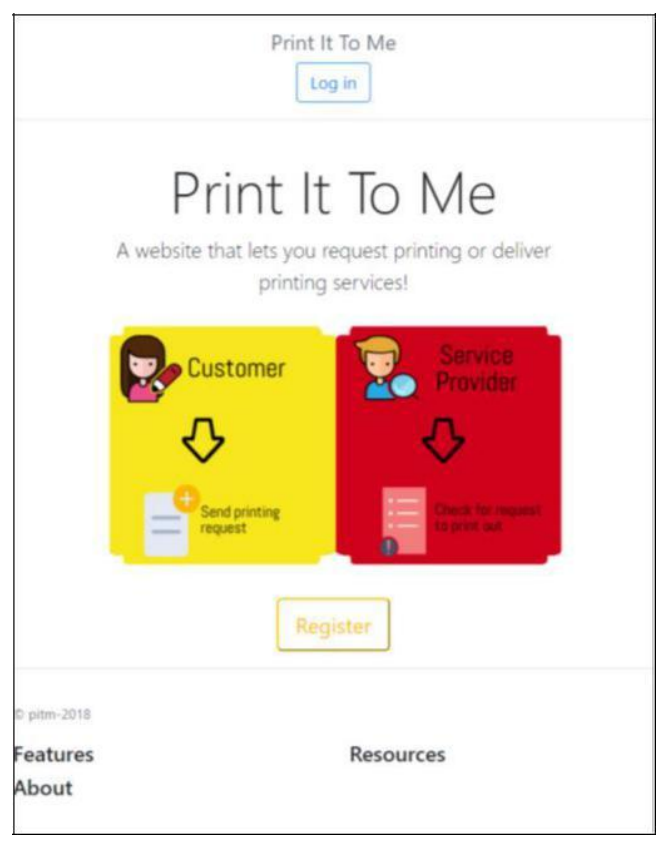

Figure 6. Index Page of Print It To Me

Figure 6 shows the user interface of the index page of Print It To Me system. The flow of the user interface is shown as in Figure 3, where users can sign in as Customer or Service Provider, or log in if they are already registered as a user.

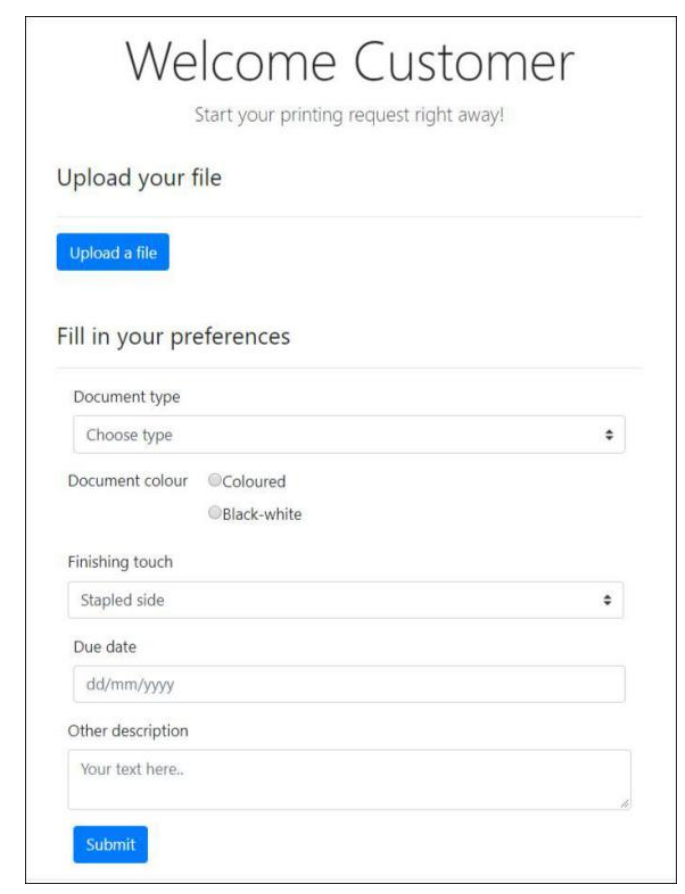

Figure 7. Customer Index Page 
Vol. 1, No.1, July 2019, pp. 24-42

Figure 7 shows the customer printing request page. After logging in, customer can request printing by uploading the document and fill in the printing preferences.

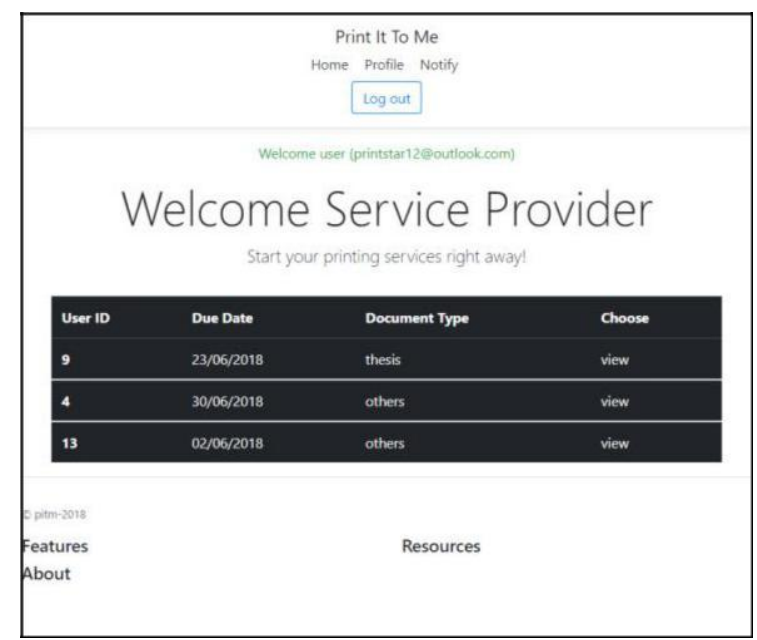

Figure 8. Service Provider Index Page

Figure 8 shows the user interface of index page of Service Provider (SP). After SP has logged, the system will show a list of available customer requests to be chosen.

The following interfaces of pages in the Print It To Me system are attached in the Appendix page.

\section{V.SYSTEM ANALYSIS AND DESIGN}

\section{A. Introduction}

This section discusses the final phase of the proposed web-based system which is the implementation and testing phase. The implementation phase is carried out to make sure that the previous phases, analysis and design phases are fulfilled. The testing phase examines the system functionality to ensure that the proposed system is meeting all requirements and user demand. Two types of tests are carried out which are functionality testing and usability testing. This phase is significant for detecting the system's strength and weaknesses.

\section{B. Implementation}

In the implementation phase of the proposed system, ASP.NET is the platform used and C\# was chosen in writing codes and running them to build the proposed system. $\mathrm{C \#}$ is used to design the backend and HTML is for frontend. This application also involves in built in SQL Server Data Tools database implementation for the system.

\section{Testing}


Vol. 1, No.1, July 2019, pp. 24-42

Functional testing and usability testing of the proposed system was carried out in this phase. Test results are considered successful only when results matches the expected results.

\section{1) Functional Testing}

Functional testing output for user clicks in the system is presented here. Table 7 displays the test results of clicking options on the proposed system.

Table 7. Test Results of Click Options

\begin{tabular}{|c|l|l|l|}
\hline No. & Test Case & Expected Output & Actual Output \\
\hline 1. & $\begin{array}{l}\text { User click which } \\
\text { user to choose } \\
\text { customer or } \\
\text { service provider) }\end{array}$ & $\begin{array}{l}\text { Redirect to } \\
\text { registration page of } \\
\text { either }\end{array}$ & As expected \\
\hline 2. & $\begin{array}{l}\text { Customer click } \\
\text { due date from } \\
\text { calendar }\end{array}$ & Date is selected & As expected \\
\hline 3. & $\begin{array}{l}\text { Customer click } \\
\text { documents to }\end{array}$ & $\begin{array}{l}\text { Document is } \\
\text { selected to be }\end{array}$ & As expected \\
\hline 4. & $\begin{array}{l}\text { Service provider } \\
\text { uplicks customer }\end{array}$ & $\begin{array}{l}\text { Page redirect to } \\
\text { customer request } \\
\text { details page }\end{array}$ & As expected \\
\hline 5. & $\begin{array}{l}\text { Service provider } \\
\text { clicks notify }\end{array}$ & Customer is notified & As expected \\
\hline
\end{tabular}

Functional testing output for user input in the system is presented here. Table 8 displays the test results of clicking options on the proposed system.

Table 8. Test Results of User Input

\begin{tabular}{|c|l|l|l|}
\hline No. & Test Case & Expected Output & Actual Output \\
\hline 1. & User input & Details appear in & As expected
\end{tabular}

Haezal Ann Dicken et.al (Print It To Me) 
Vol. 1, No.1, July 2019, pp. 24-42

\begin{tabular}{|c|l|l|l|} 
& registration details & the form & \\
\hline 2. & $\begin{array}{l}\text { User input login } \\
\text { details }\end{array}$ & $\begin{array}{l}\text { Details appear in } \\
\text { the form }\end{array}$ & As expected \\
\hline 3. & $\begin{array}{l}\text { Customer input } \\
\text { printing details }\end{array}$ & $\begin{array}{l}\text { Details appear in } \\
\text { the form }\end{array}$ & As expected \\
\hline 4. & $\begin{array}{l}\text { Customer input } \\
\text { feedback comment }\end{array}$ & $\begin{array}{l}\text { Details appear in } \\
\text { the form }\end{array}$ & As expected \\
\hline
\end{tabular}

Functional testing output for user clicking on buttons in the system is presented here. Table 9 displays the test results of button on the proposed system.

Table 9. Test Results of Button Testing

helps to detect any failing in the system, in terms of user experience, and the detected weakness of

\begin{tabular}{|c|c|c|c|}
\hline No. & Test Case & Expected Output & Actual Output \\
\hline 1. & $\begin{array}{l}\text { User click } \\
\text { customer or } \\
\text { service provider } \\
\text { button }\end{array}$ & $\begin{array}{l}\text { Redirected to } \\
\text { registration page of } \\
\text { either }\end{array}$ & As expected \\
\hline 2. & $\begin{array}{l}\text { Customer click } \\
\text { Upload button }\end{array}$ & $\begin{array}{l}\text { Document is } \\
\text { uploaded }\end{array}$ & As expected \\
\hline 3. & $\begin{array}{l}\text { SP click notify } \\
\text { button }\end{array}$ & Customer is notified & As expected \\
\hline 4. & $\begin{array}{l}\text { Customer click } \\
\text { submit button for } \\
\text { feedback }\end{array}$ & $\begin{array}{l}\text { Feedback is } \\
\text { submitted to the } \\
\text { system }\end{array}$ & As expected \\
\hline
\end{tabular}

the system is taken to action by improving them. The testing forms were given to users for answering while they test the system usability, which can be found in Appendix.

\section{CONCLUSION}

\section{1) Future Works}


Vol. 1, No.1, July 2019, pp. 24-42

The limitations stated in the previous section are future works to be put into consideration which can help the system to be better for use. This system should be built so that it can be implemented in other communities, not only of universities. This could help people make ease of their experience in finding a printing service and also helps people to get a part-time job in providing printing services. The system should also be able to provide printing service for posters, banners, etc. by creating a section in the service provider (SP) options where they can provide printing for these types of files. The system should establish a more secure connection with the web server, preferably HTTPS connection with an authentic SSL certificate. This will ensure the integrity and security of the data in the system.

\section{2) Conclusion}

In conclusion, the proposed system has been developed and the project's objectives have been achieved. While the system may contain some flaws and limitations, it can be improved by making improvements in increasing its capabilities and functionality so that it can benefits the user better.

Functional testing output for user clicking on buttons in the system is presented here. Table 9 displays the test results of button on the proposed system.

\section{2) Usability Testing}

The usability testing involved users who are going to test the system which are people from within UTHM either students or staff, both types of user can choose to be either customer or service provider (SP). The test

\section{Referrence}

1) DeBiase, P., Parlett-Sweeney, M. (2010, April 5). Student

2) Printing. Retrieved from

3) https://www.google.com/search?q=analysis + of + student + printing\&oq=ana\&aqs $=$ chrome. $2.69 \mathrm{i}$ 57j69i5912j69i60j0j69i61.271 6j0j9\&sourceid=chrome\&ie=UTF-8

4) Equity [Def.1]. (n.d.). English Oxford Living Dictionaries. In Oxford Dictionaries. Retrieved from https://en.oxforddictionaries.com/definition/equity

5) Visual Studio Blog. (2017, March 7). Announcing Visual Studio 2017 General Availability... and more. Retrieved from https://blogs.msdn.microsoft.com/visualstudio/2017/03/07/an nouncing-visual-studio-2017general-availability-and-more/

6) Tan, Emily. (2017, June 7). Diageo, Deliveroo and Toms trial start-up that gives students free printing for watching ads.

7) Heede, Tobias. (2015, September 1). Printing revolution has begun in Viby (Danish). Retrieved from https://stiften.dk/erhverv/Printer-revolution-er-startet-i-Viby/artikel/267836 
Vol. 1, No.1, July 2019, pp. 24-42

8) Bourne, M., Mills, J., Wilcox, M., Neely, A., \& Platts, K. (2000). Designing, implementing and updating performance measurement systems. International journal of operations \& production management, 20(7), 754-771. 